\title{
PHYSICAL, CHEMICAL AND MECHANICAL CHARACTERIZATION OF Acrocarpus fraxinifolius CULTIVATED IN SAO PAULO
}

\author{
Karina A. de Oliveira ${ }^{1, \star}$ \\ https://orcid.org/0000-0001-7307-7912 \\ Carolina A. Barros Oliveira ${ }^{1}$ \\ https://orcid.org/0000-0002-2253-7322 \\ Julio C. Molina ${ }^{2}$ \\ https://orcid.org/0000-0002-6204-0206
}

\begin{abstract}
Indian cedar (Acrocarpus fraxinifolius) is a wood species that occurs naturally in India, Myanmar (Burma) and Bangladesh, and has a high commercial value, with characteristics like mahogany and native cedars. The planting of Indian cedar has been undertaken in Brazil, but there is little information available regarding the characterization of the species. Therefore, considering its timber potential and its possibility of development in the country, the present work aimed to evaluate the physical, chemical, and mechanical properties of 9-year-old Indian cedar wood, planted in the southern region of Brazil. A low specific mass $\left(502 \mathrm{~kg} / \mathrm{m}^{3}\right)$, low average dimensional stability (anisotropy coefficient of 2,09\%) was observed, in addition to the low content of extractives (1,94\%). From the mechanical characterization, an average value for the elastic modulus of 8963 MPa was obtained, and for the compressive strength parallel to the grain the average and characteristic values were $32,14 \mathrm{MPa}$ and 21,46 MPa, respectively. This indicates that this wood belongs to resistance class C20 (dicotyledons). The results obtained classify the wood for use in light, external, or internal civil construction
\end{abstract}

Keywords: Acrocarpus fraxinifolius, chemical properties, Indian cedar, mechanical properties, physical properties.

\section{INTRODUCTION}

Brazil has the largest area of tropical forest in the world and has been successful in introducing species from other countries, as happened in the case of the Eucalyptus and Pinus genera. In addition to these species, other species have aroused the interest of Brazilian researchers for diversifying their use in the timber industry, such as Toona ciliata var. Australis (better known as Australian cedar) and Acrocarpus fraxinifolius (known as Indian cedar).

Acrocarpus fraxinifolius Wight \& Arn is a specie that belongs to the Fabaceae family, and popularly known as Indian cedar. This species is native to tropical regions of Asia, such as India, Myanmar (Burma) and Bangladesh (Carvalho 2010) and is widely used in civil construction, in the furniture industry and the manu- 
facture of cellulose and paper (Trianoski et al. 2011, Firmino et al. 2015).

The Indian cedar fits into the patterns of rapid growth, being considered promising for reforestation, reaching 20 meters to 40 meters in height, with leaves composed and divided (Higa and Prado 1998, Lorenzi et al. 2003).

The correct use of wood is essential to know its physical and mechanical properties, as it is this information that enables the use of the material safely in the face of eternal stresses arising from the use of the material (Oliveira 2007, Matos and Molina 2016).

In Brazil, the Indian cedar timber species is practically unknown, especially concerning the values of its mechanical properties. Only a few studies on its physical and chemical characteristics can be found, such as the one carried out by Prado et al. (2003) who concluded that the species produces light wood $\left(438 \mathrm{~kg} / \mathrm{m}^{3}\right)$, with short fibers $(1,2 \mathrm{~mm})$, high content of total extractives $(10,6 \%)$, low content of lignin $(20,1 \%)$, low shrinkage values $(0,7 \%, 3,0 \%$ and $5,4 \%$ in the axial, radial and tangential directions, respectively) and with an acceptable anisotropy coefficient $(1,8 \%)$. Such characteristics were considered by Prado et al. (2003) as appropriate for mechanical processing and furniture making.

Other studies have shown that this species has low natural durability, can easily be impregnated with preservatives, has easy processing properties, in addition to good adhesive bonding (Trianoski et al. 2011).

The characterization of the wood was done in the laboratory, using specimens free of defects and with dimensions standardized by the Brazilian standard ABNT NBR 7190 (1997), which presents recommendations for carrying out physical and mechanical tests. The characterization tests are analogous to those recommended in the international standard ISO 13061 (2017).

For the complete characterization recommended by the standard for unknown species, like the Indian cedar wood, the values of resistance to compression, tension, shear strength, and embedding strength parallel and normal to the grain are determined, as well as the values of splitting strength, Janka hardness, strength on static bending, and the modulus of elasticity. Also are required the values of basic and apparent density.

There are no recommendations in the ABNT NBR 7190 (1997) text about the minimum number of repetitions of specimens for a given property, but in the revision project of this standard at least 40 repetitions are recommended for the tests.

The analyzed wood is a species of dicotyledon (i.e. hardwood), that is little known in Brazil, but which is being used by many wood industries mainly in the manufacture of furniture. The knowledge of its physical, chemical, and mechanical characteristics may contribute to the improvement of the classification and selection of wood with the desired characteristics for a specific application.

\section{MATERIALS AND METHOD}

The material studied was wood of the Indian cedar (Acrocarpus fraxinifolius Wight \& Arn), from the planting of Cedar Valley Company, located in Ribeirao Branco, in the southwest region of the state of Sao Paulo, Brazil. The tests were performed at the Laboratory of Mechanical Properties, Department of Wood Industrial Engineering, São Paulo State University (UNESP).

The samples of Indian cedar wood were properly stored, which resulted in equilibrium moisture content close to $12 \%$ according to ABNT NBR 7190 (1997). For each test, 40 repetitions of specimens were considered.

\section{Physical characterization tests}

To determine the physical properties of the wood, the tests of apparent density $\left(\rho_{\mathrm{ap}, 12 \%}\right)$, volumetric variation, shrinkage $\left(\varepsilon_{\mathrm{r}}\right)$, and swelling $\left(\varepsilon_{\mathrm{i}}\right)$ were performed according to the Brazilian standard ABNT NBR 7190 (1997), using specimens of rectangular cross section, with nominal dimensions of $30 \mathrm{~mm}$ x $20 \mathrm{~mm}$ x 50 $\mathrm{mm}$.

First, the apparent density of the specimen at $12 \%$ moisture content was determined. The material was then submerged in water, with a grid was placed over the specimens to keep the material completely under water, to perform the basic density and shrinkage tests $\left(\varepsilon_{\mathrm{r}}\right)$. 
After a period of 48 hours of submersion in water, the specimens began to be weighed every 6 hours until they reached constant mass or had a variation of less than $0,5 \%$ about the previous measurement. The total period of submersion in water until constant mass was 145 hours.

Upon reaching constant mass, the specimens were measured in three dimensions, obtaining the final mass and volume. Subsequently, the specimens were kept in an oven at $103{ }^{\circ} \mathrm{C} \pm 2{ }^{\circ} \mathrm{C}$, with measurements of mass and dimensions being performed every six hours until a difference of $0,5 \%$ or less from the previous measurement.

For the study of swelling $\left(\varepsilon_{\mathrm{i}}\right)$, the dry specimen was placed in water to be rehydrated, with measurements (dimensions, mass, and volume) being carried out every 6 hours until reaching constant mass or variation of at most $0,5 \%$ about the previous measurement, following the same procedures performed in the shrinkage test.

\section{Chemical characterization tests}

The methodology for determining the extraction of wood was carried out according to the methods M3/69 (ABTCP 1974) and TAPPI T264-OM-97 (1997), which use the extraction sequence ethanol/benzene, ethanol, hot water. The ethanol/benzene mixture was replaced by ethanol/toluene, as benzene is a carcinogenic product and many laboratories in Brazil and worldwide are abandoning the use of this product.

The determination of lignin was performed according to the Klason method, based on the TAPPI T222OM-02 (2002) standard, which consists of treating the sample, free of extracts, with $72 \%$ sulfuric acid that dissolves the polysaccharide fraction, leaving only the lignin. The standard states that for every 1 gram of extractive-free sawdust, $15 \mathrm{ml}$ of sulfuric acid is used.

Holocellulose is the combination of cellulose and other polysaccharides, called hemicellulose. Hemicelluloses differ from cellulose, as they have different sugar units of five or six carbon atoms, and through the delignification process, ie, the removal of lignin, it was possible to obtain holocellulose. Therefore, the holocellulose content was calculated by difference, through Equation 1:

$$
\text { Holocellulose }(\%)=100-(\text { total extracts }+ \text { total lignin })
$$

\section{Mechanical characterization tests}

The tests for the complete characterization of the mechanical resistance properties were obtained in accordance with the requirements of the Brazilian standard ABNT NBR 7190 (1997), set out in its Annex B, using the universal testing machine EMIC with an automated data acquisition system and capacity for $300 \mathrm{kN}$.

Mechanical tests were performed to determine the compressive strength parallel and normal to the grain $\left(f_{c 0}\right.$ and $\left.f_{c 90}\right)$, tensile strength parallel and normal to fibers $\left(f_{t 0}\right.$ and $\left.f_{t 90}\right)$, shear strength parallel to the grain $\left(f_{v 0}\right)$, embedding strength parallel and normal to fibers $\left(\mathrm{f}_{\mathrm{e} 0}\right.$ and $\left.\mathrm{f}_{\mathrm{e} 90}\right)$, splitting strength $\left(\mathrm{f}_{\mathrm{s} 0}\right)$, Janka hardness parallel and normal to the grain $\left(\mathrm{f}_{\mathrm{H} 0}\right.$ and $\left.\mathrm{f}_{\mathrm{H} 90}\right)$, conventional strength on static bending test $\left(\mathrm{f}_{\mathrm{M}}\right)$, modulus of elasticity in parallel and normal directions to the grain $\left(\mathrm{E}_{\mathrm{c} 0, \mathrm{~m}}\right.$ and $\left.\mathrm{E}_{\mathrm{c} 90, \mathrm{~m}}\right)$, modulus of elasticity in tension parallel to the grain $\left(\mathrm{E}_{\mathrm{t} 0, \mathrm{~m}}\right)$, and conventional modulus of elasticity on static bending test $\left(\mathrm{E}_{\mathrm{M}, \mathrm{m}}\right)$. Figure 1 describes the dimensions of wood specimens.
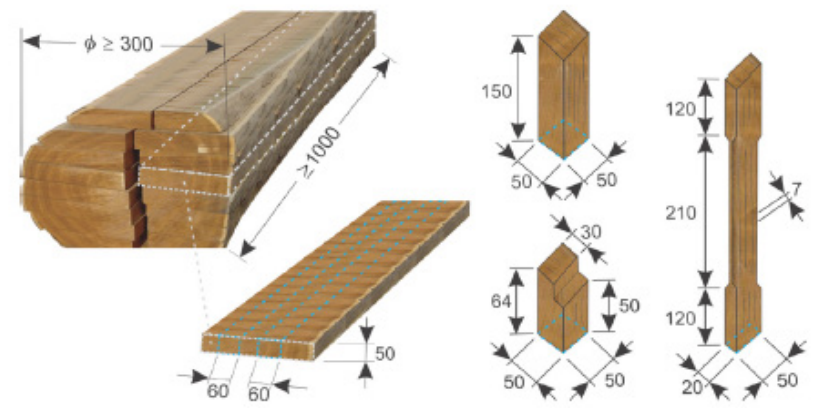

Figure 1: Dimension of wood specimens and description of their extraction on timber. (units in mm. Source: Morando et al. 2019). 
It should be noted that 40 specimens for each one of its mechanical properties were investigated. The Indian cedar (Acrocarpus fraxinifolius) wood was classified in the appropriate strength class for the dicotyledon group according to the characteristic value of the compressive strength parallel to the fibers $\left(\mathrm{f}_{\mathrm{c} 0 \mathrm{k}}\right)$, as specified in the Brazilian standard ABNT NBR 7190 (1997).

Simplified relationships between strength and stiffness values were proposed for the wood under study. The simplified relationships between the strengths considered the characteristic value of the compressive strength parallel to the grain $\left(\mathrm{f}_{\mathrm{c} 0, \mathrm{k}}\right)$ according to ABNT NBR 7190 (1997).

For the statistical treatment of the data, the Anderson Darling normality test was used, to verify whether the values obtained followed a normal distribution. The level of $5 \%$ of significance $(\alpha=0,05)$ was admitted, and p-value $>0,05$ meant that the data followed a trend of normality.

\section{Classification of wood according to Sallenave (1955)}

The classification method of Sallenave (1955), recognized nationally and internationally, establishes a classification for the species of wood intended for application in civil construction. In this method, based on some values of the physical and mechanical properties of wood, also considering its nature, in particular, anisotropy and other characteristics due to its organic constitution, it is possible to classify the wood for a particular use. This method was considered in this study to enable types of application for the wood characterized to be suggested.

\section{RESULTS AND DISCUSSION}

\section{Physical characterization}

The basic and apparent density determined for the studied Indian cedar wood were $391 \mathrm{~kg} / \mathrm{m}^{3}$ and $502 \mathrm{~kg} /$ $\mathrm{m}^{3}$, respectively. In the literature it is possible to find studies on the apparent density of this wood, with the following results: $440 \mathrm{~kg} / \mathrm{m}^{3}$ (Prado et al. 2003), $500 \mathrm{~kg} / \mathrm{m}^{3}$ (Trianoski et al. 2011), $490 \mathrm{~kg} / \mathrm{m}^{3}$ (Tello 2009), $460 \mathrm{~kg} / \mathrm{m}^{3}$ (Trianoski 2010), and $480 \mathrm{~g} / \mathrm{cm}^{3}$ (Suirezs et al. 2015).

Density is the most significant physical property in the characterization of wood for use in civil construction, manufacture of sheets, and furniture, as several properties are related to it.

Table 1 shows the average values $\left(\mathrm{X}_{\mathrm{m}}\right)$ and the standard deviation (SD) of the specific deformations of shrinkage $\left(\varepsilon_{\mathrm{r}}\right)$ and swelling $\left(\mathcal{E}_{\mathrm{i}}\right)$ of the studied wood, according to directions 1,2 , and 3 , corresponding to the axial, radial and tangential axes of the wood.

Table 1: Results of dimensional stability tests.

\begin{tabular}{|c|c|c|c|c|c|c|c|c|}
\hline & \multicolumn{3}{|c|}{ Shrinkage } & \multicolumn{3}{c|}{ Swelling } & Volumetric & Anisotropy \\
Contraction & Coefficient \\
\hline & $\varepsilon_{\mathrm{r} 1}$ & $\varepsilon_{\mathrm{r} 2}$ & $\varepsilon_{\mathrm{r} 3}$ & $\varepsilon_{\mathrm{i} 1}$ & $\varepsilon_{\mathrm{i} 2}$ & $\varepsilon_{\mathrm{i} 3}$ & \\
\hline $\mathrm{X}_{\mathrm{m}}(\%)$ & 0,461 & 2,048 & 4,276 & 0,463 & 2,091 & 4,468 & 7,147 & 2,09 \\
\hline $\mathrm{SD}$ & 0,150 & 0,241 & 0,427 & 0,152 & 0,251 & 0,465 & 0,405 & 0,386 \\
\hline
\end{tabular}

The anisotropy coefficient, expressed by the relationship between tangential and radial skrinkage, was 2,09 $\%$, which indicates this is a suitable wood for uses that require dimensional stability. According to Oliveira and Silva (2003), this coefficient generally varies from $1,5 \%$ to $2,5 \%$ and is an important index in studies of wood contraction, because of the higher this value, the greater the tendency to crack and warp the wood.

To give you an idea, desirable values for the best possible performance concerning dimensional stability should be close to $1,0 \%$. However, hardwoods such as Tatajuba, Mahogany, and Sucupira, considered to have excellent dimensional stability, have anisotropy coefficients of $1,4 \%, 1,2 \%$, and $1,4 \%$, respectively.

According to studies by Prado et al. (2003), the shrinkage coefficients of the Indian cedar wood are 0,7 $\%, 3,0 \%$ and $5,4 \%$ for the axial, radial and tangential directions, respectively, and the anisotropy coefficient 
of $1,8 \%$. Therefore, the results obtained in this study are compatible with the values found in the literature.

Small differences observed in the results of the properties obtained can be explained by the natural variability of the wood, which can occur due to several factors, among which can be mentioned: anatomical, chemical, physical, among others, and the variations can occur even within wood from the same tree.

Indian cedar showed less dimensional stability when compared to other species such as mahogany, which has an anisotropy coefficient of 1,41 \% (Mainieri and Chimelo 1989), Swietenia mahagoni and Cedrela odorata, with contraction anisotropy between $1,2 \%$ and 1,5\%, respectively (Loureiro and Silva 1968). On the other hand, it presented greater dimensional stability when compared to Australian cedar (Toona ciliata), with a volumetric contraction of $10,56 \%$ and an anisotropy coefficient of 2,22 \% (Trianoski et al. 2014).

With the results obtained, Indian cedar wood can be considered medium to low stability, because Oliveira and Silva (2003) indicated that radial shrinkage values between 1,5\% and 2,5\%, tangential shrinkage between $3,1 \%$ and $5,0 \%$, and volumetric shrinkage between $4,6 \%$ and $7,5 \%$ related to medium to low stability class.

\section{Chemical characterization}

The results of the chemical analysis for the studied Indian cedar wood showed 1,94 \% of extractives, 31,07 $\%$ of lignin, and $68,93 \%$ of holocellulose. The values differed from those found by Prado et al. (2003) for total extracts and lignin, 10,6\%, and 20,1\%, respectively, while for holocellulose the results were similar, $69,3 \%$.

This difference in the results may be a result of the natural variability of the wood because different planting regions may present differences in their constitution due to the climate, the soil, among other planting factors.

In the study by Prado et al. (2003), the Indian cedar woods came from South Africa, Mugerê Urundi, Kenya Nairobi, Kenya Gachoila, Rwanda Butar, and Brazil, with 8 years old and with samples collected from the base to the top. While those used in this study came from the southwest of the State of Sao Paulo, Brazil, at the age of 9 , and without specifying which region of the trunk they were beams removed.

\section{Mechanical characterization}

Table 2 presents the average values $\left(\mathrm{X}_{\mathrm{m}}\right)$ and characteristic resistance values $\left(\mathrm{f}_{\mathrm{w}, \mathrm{k}}\right)$ for the complete characterization of the Indian cedar specimens. It also presents the standard deviations, the coefficients of variation $(\mathrm{CV})$, and the p-values referring to the data normality test. All results correspond to a moisture content of 12 $\%$, according to ABNT NBR 7190 (1997).

Table 2: Results of the strength properties of Indian cedar.

\begin{tabular}{|c|c|c|c|c|}
\hline Property & $\mathrm{X}_{\mathrm{m}}(\mathrm{MPa})$ & $\mathrm{f}_{\mathrm{w}, \mathrm{k}}(\mathrm{MPa})$ & $\mathrm{CV}(\%)$ & $\mathrm{p}$-value \\
\hline $\mathrm{f}_{\mathrm{c} 0}$ & $32,14 \pm 6,51$ & 21,46 & 20,25 & 0,703 \\
\hline $\mathrm{f}_{\mathrm{c} 90}$ & $6,30 \pm 0,23$ & 5,92 & 3,61 & 0,981 \\
\hline $\mathrm{f}_{\mathrm{t} 0}$ & $45,47 \pm 18,37$ & 15,34 & 40,41 & 0,676 \\
\hline $\mathrm{f}_{\mathrm{t} 90}$ & $2,91 \pm 0,56$ & 1,99 & 19,20 & 0,348 \\
\hline $\mathrm{f}_{\mathrm{v} 0}$ & $8,89 \pm 1,33$ & 6,71 & 14,76 & 0,381 \\
\hline $\mathrm{f}_{\mathrm{e} 0}$ & $18,05 \pm 3,77$ & 11,87 & 20,89 & 0,376 \\
\hline $\mathrm{f}_{\mathrm{e} 90}$ & $8,32 \pm 2,15$ & 4,79 & 25,89 & 0,262 \\
\hline $\mathrm{f}_{\mathrm{M}}$ & $50,55 \pm 9,50$ & 34,97 & 18,79 & 0,621 \\
\hline $\mathrm{f}_{\mathrm{s} 0}$ & $0,58 \pm 0,08$ & 0,45 & 13,08 & 0,508 \\
\hline $\mathrm{f}_{\mathrm{H} 0}$ & $29,31 \pm 3,05$ & 24,31 & 10,41 & 0,163 \\
\hline $\mathrm{f}_{\mathrm{H} 90}$ & $21,37 \pm 3,86$ & 15,04 & 18,07 & 0,850 \\
\hline
\end{tabular}

The simplified strength relationships obtained from the characteristic values in Table 2 were as follows: 
Table 3: simplified strength relationships from the characteristic values of Indian cedar.

\begin{tabular}{|c|c|}
\hline $\mathrm{f}_{\mathrm{c} 90, \mathrm{k}} / \mathrm{f}_{\mathrm{c} 0, \mathrm{k}}=0,18$ & $\mathrm{f}_{\mathrm{e} 90, \mathrm{k}} / \mathrm{f}_{\mathrm{c} 0, \mathrm{k}}=1,28$ \\
\hline $\mathrm{f}_{\mathrm{c} 0, \mathrm{k}} / \mathrm{f}_{\mathrm{t} 0, \mathrm{k}}=0,50$ & $\mathrm{f}_{\mathrm{M}, \mathrm{k}} / \mathrm{f}_{\mathrm{c} 0, \mathrm{k}}=0,93$ \\
\hline $\mathrm{f}_{\mathrm{t} 90, \mathrm{k}} / \mathrm{f}_{\mathrm{c} 0, \mathrm{k}}=0,95$ & $\mathrm{f}_{\mathrm{s} 0, \mathrm{k}} / \mathrm{f}_{\mathrm{c} 0, \mathrm{k}}=0,64$ \\
\hline $\mathrm{f}_{\mathrm{v} 0, \mathrm{k}} / \mathrm{f}_{\mathrm{c} 0, \mathrm{k}}=0,73$ & $\mathrm{f}_{\mathrm{H} 0, \mathrm{k}} / \mathrm{f}_{\mathrm{c} 0, \mathrm{k}}=0,51$ \\
\hline $\mathrm{f}_{\mathrm{e} 0, \mathrm{k}} / \mathrm{f}_{\mathrm{c} 0, \mathrm{k}}=1,03$ & $\mathrm{f}_{\mathrm{H} 90, \mathrm{k}} / \mathrm{f}_{\mathrm{c} 0, \mathrm{k}}=0,89$ \\
\hline
\end{tabular}

The simplified relationships proposed by ABNT NBR 7190 (1997) for dicotyledonous woods are: $\mathrm{f}_{\mathrm{cok}} / \mathrm{f}_{\mathrm{t} 0 \mathrm{k}}$ $=0,77 ; \mathrm{f}_{\mathrm{c} 90, \mathrm{k}} / \mathrm{f}_{\mathrm{c} 0, \mathrm{k}}=0,25 ; \mathrm{f}_{\mathrm{e} 0, \mathrm{k}} / \mathrm{f}_{\mathrm{c} 0, \mathrm{k}}=1,0 ; \mathrm{f}_{\mathrm{e} 90, \mathrm{k}} / \mathrm{f}_{\mathrm{c} 0, \mathrm{k}}=0,25$ and $\mathrm{f}_{\mathrm{v} 0, \mathrm{k}} / \mathrm{f}_{\mathrm{c} 0, \mathrm{k}}=0,12$. The simplified relationships related to shear and embedding strengths showed the greatest differences in relation to the normative relationships.

Table 4 presents the average values $\left(\mathrm{X}_{\mathrm{m}}\right)$ of stiffness for the characterization of the specimens of Indian cedar, the standard deviations, the $\mathrm{CV}$, and the p-values.

Table 4: Results of Indian cedar stiffness properties.

\begin{tabular}{|c|c|c|c|}
\hline Property & $\mathrm{X}_{\mathrm{m}}(\mathrm{MPa})$ & $\mathrm{CV}(\%)$ & $\mathrm{p}$-value \\
\hline $\mathrm{E}_{\mathrm{c} 0}$ & $8963 \pm 3170$ & 25,36 & 0,383 \\
\hline $\mathrm{E}_{\mathrm{c} 90}$ & $502 \pm 52,03$ & 10,38 & 0,725 \\
\hline $\mathrm{E}_{\mathrm{M}}$ & $7506 \pm 2246$ & 29,92 & 0,437 \\
\hline
\end{tabular}

The characteristic value $\left(\mathrm{f}_{\mathrm{c} 0, \mathrm{k}}\right)$ obtained for the compressive strength parallel to the grain was 21,46 MPa and the modulus of elasticity in parallel directions to the grain $\left(\mathrm{E}_{\mathrm{co}}\right)$ was $8963 \mathrm{MPa}$. Considering these values, this wood is classified as being class C20 for hardwoods (dicotyledons), according to the standard ABNT NBR 7190 (1997).

This modulus of elasticity in parallel directions to the grain $\left(\mathrm{E}_{\mathrm{c} 0}\right)$ obtained for Indian cedar wood is close to the values of Sweet cedar (8058 MPa), Bitter cedar (9836 MPa) and Pinus caribaea (8431 MPa), but it is lower than the values presented for other reforestation woods such as Eucalyptus grandis (12813 MPa), Pinus elliottii (11889 MPa) and Pinus taeda (13304 MPa) (ABNT 7190 1997).

Analyzing the values of the coefficients of variation, the Brazilian standard ABNT NBR 7190 (1997) establishes that the maximum value of the coefficient of variation allowed for the characterization to be considered adequate should be $18 \%$ for normal efforts and $28 \%$ for tangential efforts. The tensile strength parallel to fibers $\left(f_{t 0}\right)$ presented a value above that allowed by norm. This may occur due to the inherent variability in the tensile strength test parallel to the fibers (Christoforo et al. 2020).

According to a classification based on the criteria of Sallenave (1955), Indian cedar wood has a density considered very light $\left(\leq 500 \mathrm{~kg} / \mathrm{m}^{3}\right)$, it was very soft in Janka hardness tests, and had weak cracking resistance $(<1,5 \mathrm{MPa})$.

Therefore, a possible structural application for the wood in question would be in light constructions with external or internal use. However, for external use it requires preservative treatment.

It should be noted that the wood used in the development of this research was 9 years old, so it has a large amount of juvenile wood. Structural parts that contain a certain amount of juvenile wood have lower strength classes, as the mechanical properties of wood are strongly influenced by various factors, such as tree age, grain angle, moisture content, temperature, chemical constituents, specific mass, anatomical constitution, duration of tension and deformation, wood failures and the presence of knots. Thus, the presence of juvenile and mature wood, in any proportion, will interfere with the mechanical properties.

The simplified stiffness relationships obtained from the mean values in Table 3 were $\mathrm{E}_{\mathrm{c} 90, \mathrm{~m}} / \mathrm{E}_{\mathrm{c} 0, \mathrm{~m}}=0,06$ and $\mathrm{E}_{\mathrm{M}, \mathrm{m}} / \mathrm{E}_{\mathrm{c} 0, \mathrm{~m}}=0,84$. The simplified stiffness ratios proposed by ABNT NBR 7190 (1997) for dicotyledonous woods are $\mathrm{E}_{\mathrm{c} 90, \mathrm{~m}} / \mathrm{E}_{\mathrm{c} 0, \mathrm{~m}}=0,05$ and $\mathrm{E}_{\mathrm{M}, \mathrm{m}} / \mathrm{E}_{\mathrm{c} 0, \mathrm{~m}}=0,90$. 


\section{CONCLUSIONS}

Based on the results presented in the present research, it is concluded that the characterization of the species Indian cedar wood (Acrocarpus fraxinifolius) was adequate, following the precepts presented in the Brazilian standard.

With the mechanical results obtained, the Indian cedar wood (Acrocarpus fraxinifolius) was classified in class $\mathrm{C} 20$ of the hardwoods (dicotyledons), based on the characteristic value of the compressive strength parallel to the grain.

It was also observed that it is a light wood, with medium dimensional stability, and that it has strength and stiffness values compatible with other reforestation species such as Sweet cedar, Bitter cedar, and Pinus caribaea cultivated in Brazil. However, Indian cedar has lower values when compared to the most used reforestation woods in Brazil, such as Eucalyptus grandis, Pinus elliottii and Pinus taeda.

Therefore, plantation grown juvenile Indian cedar wood can be used in cases that do not require great efforts, such as roof elements, beams, shutters, doors, fittings, ceilings, baseboards, and furniture.

So, the results obtained refer to the studied wood lot and not the Indian cedar species in general, because for a general result it would be necessary to obtain samples of the same species, with different ages and from different planting regions.

\section{ACKNOWLEDGEMENTS}

This work was carried out with the support of the Coordination for the Improvement of Higher Education Personnel - Brazil (CAPES) - Financing Code 001.

\section{REFERENCES}

ABTCP. 1974. Métodos de ensaio. ABTCP. M3-69. 1974. Sao Paulo, SP, Brazil.

ABNT. 1997. Projeto de estruturas de madeira. NBR 7190:1997.

Carvalho, P.E.R. 2010. Espécies Arbóreas Brasileiras. Embrapa Informação Tecnológica, Brasília, DF, Brazil. https://livimagens.sct.embrapa.br/amostras/00083860.pdf

Christoforo, A.L.; Couto, N.G.; Almeida, J.P.B.; Aquino, V.B.M.; Lahr, F.A.R. 2020. Apparent density as an estimator of wood properties obtained in tests where failure is fragile. Eng Agric 40(1): 105-112. https://doi.org/10.1590/1809-4430-Eng.Agric.v40n1p105-112/2020

Firmino, A.C.; Moraes, W.B.; Furtado, E.L. 2015. Primeiro relato de Ceratocystis fimbriata causando seca em Acrocarpus fraxinifolius no Brasil. Summa Phytopathol 41(2): 160. http://dx.doi.org/10.1590/0100$5405 / 1954$

Higa, A.R.; Prado, C.A. 1998. Acrocarpus fraxinifolius Wight \& Arn. In Non-traditional species for planting for productive and environmental purposes. Galvão, A.P.M. (Ed.). Colombo: Embrapa Florestas. CRC Press, Brazil. 57-60. https://ainfo.cnptia.embrapa.br/digital/bitstream/item/105277/1/Acrocarpusfraxinifolius0001.pdf

ISO. 2017. Physical and mechanical properties of wood. Test methods for small clear wood specimens. ISO 13061: 2017. Geneva, Switzerland. https://www.iso.org/standard/60079.html

Lorenzi, H.; Souza, H.M.; Torres, M.A.V.; Bacher, L.B. 2003. Árvores exóticas no Brasil: madeireiras, ornamentais e aromáticas. Nova Odessa: Instituto Plantarum. (In Portuguese). 

se).

Loureiro, A.A.; Silva, M.F. 1968. Catalog of Amazonian woods. SUDAM: Belém, Brazil. (In Portugue-

Mainieri, C.; Chimelo, J.P. 1989. Fichas de características das madeiras brasileiras. Instituto de Pesquisa Tecnológica - IPT: São Paulo, SP, Brazil. (In Portuguese).

Matos, G.S.; Molina, J.C. 2016. Resistência da madeira ao cisalhamento paralelo às fibras segundo as normas ABNT NBR 7190:1997 e ISO 13910:2005. Matéria 21(4): 1069-1079. https://doi.org/10.1590/s1517707620160004.0098

Morando, T.C.; Christoforo, A.L.; Aquino, V.B.M.; Lahr, F.A.R.; Rezende, G.B.M.; Ferreira, R.T.L. 2019. Characterization of the wood species Qualea albiflora for structural purposes. Wood Research 64(5): 769-776. http://www.woodresearch.sk/wr/201905/02.pdf

Oliveira, J.T.S.; Silva, J.C. 2003. Radial variation of shrinkage and basic density of Eucalyptus saligna wood. Rev Arvore 27(3): 381-385. https://doi.org/10.1590/S0100-67622003000300015

Oliveira, J.T.S. 2007. Propriedades físicas e mecânicas da madeira. In Tecnologias aplicadas ao setor madeireiro. Oliveira, J.T.S.; Fiedler, N.C.; Nogueira, M. (Ed.) Suprema Gráfica e Editora Ltda. CRC Press: Visconde do Rio Branco, Brazil. 129-163.

Prado, C.A.; Pereira, J.C.D.; Mattos, P.P.; Schaitza, E.G.; Higa, A.R. 2003. Physical and chemical characteristics of Acrocarpus fraxinifolius Wight \& Arn. Emprapa Florestas: Colombo, Brazil. http://www.infoteca.cnptia.embrapa.br/infoteca/handle/doc/281002

Sallenave, P. 1955. Propriétés physiques et mécaniques des bois tropicaux de L’Union française. Nogent-sur-Marne. Centre Technique Forestier Tropical. CRC Press: France. 128p. https://doi.org/10.18167/agritrop/00359

Suirezs, T.; Arenhardt, O.; Stehr, A.; Bobadilla, E.; Weber, E.; Gragañolo, A. 2015. Natural durability and apparent specific weights of Acrocarpus fraxinifolius wight $\&$ arn (Pink cedar) cultivated in the Province of Misiones, Argentina. Procedia Materials Science 8: 802-806. https://doi.org/10.1016/j.mspro.2015.04.138

TAPPI. 1997. Preparation of wood for chemical analysis. T264-CM-97. Atlanta, USA.

TAPPI. 2002. Acid-insoluble lignin in wood and pulp. T222-OM-02. Atlanta, USA.

Tello, J. 2009. Physic-mechanical characterization of Acrocarpus fraxinifolius wood. Ph.D. Thesis, College of Wood Technology Engineer, University Michoacana de San Nicolás de Hidalgo, Mexico.

Trianoski, R. 2010. Avaliação do potencial de espécies florestais alternativas, de rápido crescimento, para produção de painéis de madeira aglomerada. Dissertation, Federal University of Paraná, Curitiba, Brazil. https://acervodigital.ufpr.br/handle/1884/24136

Trianoski, R.; Iwakiri, S.; Matos, J.L.M.; Prata, J.G. 2011. Viabilidade da utilização de Acrocarpus fraxinifolius em diferentes proporções com Pinus taeda para produção de painéis aglomerados. Sci For 39(91): 343-350. https://www.ipef.br/publicacoes/scientia/nr91/cap06.pdf

Trianoski, R.; Matos, J.L.M.; Iwakiri, S. 2014. Propriedades físicas, químicas e mecânicas da madeira de cedro australiano cultivado em Corupá, SC. Pesq Flor Bras 34(80): 435-441. https://doi.org/10.4336/2014. pfb.34.80.523 